\title{
Determination of Antimicrobial Effects of Probiotic Lactic Acid Bacteria and Garlic Extract Against Some Foodborn Pathogenic Bacteria
}

\author{
Elçin Taş ${ }^{1}$, Zerrin Erginkaya ${ }^{1}$, Selin Kalkan ${ }^{2 *}$, Emel Ünal Turhan ${ }^{3}$ \\ ${ }^{1}$ Department of food Engineering, Faculty of Agriculture, Cukurova University, 01330 Adana, Turkey \\ ${ }^{2}$ Department of Food Engineering, Faculty of Engineering, Giresun University, 28200 Giresun, Turkey
}

${ }^{3}$ Department of Food Technology, Kadirli Applied Sciences School, Osmaniye Korkut Ata University, 80750 Osmaniye, Turkey

\begin{tabular}{ll}
\hline A R T I C L E I N F O & A \\
Research Article & In \\
Received 29 August 2016 & Accepted 30 November 2016 \\
\hline
\end{tabular}

Keywords:

Lactic acid bacteria

Inhibition effect

Food-borne pathogens

Garlic extract

Probiotic

*Corresponding Author: \begin{abstract}
A B S T R A C T
In this study, it was investigated that the inhibition effect of some lactic acid bacteria (Lactobacillus acidophilus NCC68, Lactobacillus casei Shirota, Lactobacillus rhamnosus (Ezal, commercial starter cultures)) which possessed with probiotic characteristics, against Bacillus cereus, Salmonella Enteritidis, Escherichia coli, Escherichia coli 0157:H7 ATCC 35150 and Staphylococcus aureus ATCC 25923. Besides, the inhibitory effect of probiotic cultures which used with meat and meat product additives that garlic extract over the antagonistic effects of sensitive pathogens were investigated in vitro. Consequently, the whole of lactic acid bacteria and garlic extract which were used in this study, showed inhibition effects against all selected pathogenic bacteria. Staphylococcus aureus ATCC 25923 was determined as the most sensitive pathogenic bacteria while Bacillus cereus was the most resistant bacteria against lactic acid bacteria and garlic extract. There was a distinctive increase in inhibition effects were observed by used of a combination with lactic acid bacteria and garlic extract.
\end{abstract}

E-mail: selin.kalkan@giresun.edu.tr

\section{Introduction}

During the recent years alternative and efficient compounds for food preservation aimed at a partial or total replacement of antimicrobial chemical additives have been studied (Ranjan, 2012). Natural foods without chemical preservatives have been preferred by healthconscious consumers that will fit in their healthy lifestyle and this situation led to increase the interest in food preservation. Biopreservation is the use of natural microbiota or antimicrobials as a way of preserving food and extending its shelf life. The biopreservation of food, especially utilizing lactic acid bacteria (LAB) or herbal extract such as garlic that are inhibitory to food spoilage microbes has been practiced since early ages (Cizeikene, 2013; Reis, 2012).

Biopreservation using lactic acid bacteria (LAB) improves food safety. The antimicrobial properties of LAB are mainly related to the production of antimicrobial active metabolites such as organic acids (mainly lactic and acetic acid), hydrogen peroxide and also other compounds, such as bacteriocins and antifungal peptides (Hayaloğlu and Erginkaya, 2001; Reis, 2012). LAB has the ability to inhibit spoilage and foodborne pathogenic bacteria. As a matter of fact LAB exhibit a broad antimicrobial activity against species of A. hydrophila, $S$. aureus, E.coli and L. monocytogenes, Proteus, Salmonella, Bacillus and Streptococcus (Reis, 2012; Ghanbari, 2013; Siroli 2015; Argues, 2015).
Herbs have been used for many centuries by various cultures in food preservation and in the treatment of clinical ailments (Kumar, 2014). Especially garlic and its extract have been used for centuries in various countries to treat infectious disease. Garlic can be more effective as a broad-spectrum antibiotic compared with conventional antibiotics (Li, 2015). The antimicrobial activity and other therapeutic benefits of garlic have been widely recognized. The antimicrobial activity of garlic has long been recognized, with allicin, other thiosulfinates, and their transformation products having antimicrobial activity (Kyung, 2012). Garlic extracts exhibited activity against both Gram negative (E. coli, Salmonella spp. and Citrobacter spp., Enterobacter spp., Pseudomonas spp., Helicobacter pylori, Klebsiella spp.) and Gram positive (S. aureus, S. pneumoni, Group A Streptococcus spp., Clostridium botulinum, Mycobacterium spp. and Bacillus anthrax) (Daka, 2011; Mukhtar, 2012; Casella, 2013, Gulfraz, 2014).

E. coli $\mathrm{O} 157: \mathrm{H} 7$ is one of hundreds of strains of the bacterium Escherichia coli. Although most strains of $E$. coli are harmless, this strain produces a powerful toxin that can cause severe illness (Oz et al., 2002; Boyce et al., 1995). Staphylococcus aureus is responsible of food poisoning incidents in many types of food, including fermented sausages. Under suitable conditions, S. aureus can multiply and produce toxin during the initial stage of 
fermentation (Sameshima et al., 1998). Bacillus cereus is a well-known food poisoning organism that may cause illness through the production of either an emetic (vomitinducing) toxin or at least three diarrheal toxins (enterotoxins) (Granum, 2001). In addition to, this strain is known to be responsible for a variety of spoilage problems in many processed foods and dairy products (Meer et al., 1991; Andersson et al., 1995; Larsen and Jørgensen, 1997; Mayr et al., 1999). Salmonella Enteritidis have been implicated in approximately $50 \%$ of the foodborne salmonellosis outbreaks in the United States. Many outbreaks are caused by $S$. Enteritidiscontaminated shell eggs, including eggs used in such traditional recipes as eggnog and Caesar salad (Pascual et al., 1999).

In this study, it was aimed to determine in vitro antimicrobial activity of probiotic lactic acid bacteria, garlic extract and their combination against some important foodborne pathogenic bacteria such as E. coli, E. coli O157:H7 ATCC 35150, B. cereus, S. aureus ATCC 25923, $S$. Enteritidis.

\section{Materials and Methods}

\section{Microorganisms}

In this study, as probiotic cultures, Lactobacillus case Shirota, Lactobacillus acidophilus NCC68 and Lactobacillus rhamnosus (Ezal, commercial starter cultures) were used. Also E. coli, E.coli O157:H7 ATCC 35150, B. cereus, S. Enteritidis and S. aureus ATCC 25923 were used. The lactic acid bacteria and pathogen strains were grown respectively in MRS broth (Merck) at $30^{\circ} \mathrm{C}$, for $48 \mathrm{~h}$ and in BHI broth (Merck) at $37^{\circ} \mathrm{C}$ for $24 \mathrm{~h}$. These cultures were kept as frozen stock cultures at $-20^{\circ} \mathrm{C}$ and propagated twice before using in inhibition assays.

\section{Preparation of Garlic Extract}

The fresh garlic was purchased from the local market. In order to obtain the garlic's extracts, $100 \mathrm{~g}$ of the cleaned garlic were sterilized using ethanol. The ethanol was allowed to evaporate in a sterile laminar flow chamber, and the garlic was homogenized aseptically using a sterile mortar and pestle. The extract was aseptically squeezed out using sterile cheesecloth. (Indu et al., 2006).

\section{Preparation of Lactic Acid Bacteria Supernatant}

LAB colony cells were harvested anaerobically at $30^{\circ} \mathrm{C}$ for $24 \mathrm{~h}$ in MRS (de Man, Rogosa and Sharpe) broth until the cultures reached about $10^{8} \mathrm{CFU} / \mathrm{ml}$ and cell free supernatant from each LAB strain were prepared by centrifugation (Sepatech Labofuge 200, Heraeus, Germany) at $5000 \times \mathrm{g}$ for $15 \mathrm{~min}$. The pellet was washed twice with sterile physiological saline solution $(0.85 \%$ $\mathrm{NaCl}$ ) and resuspended in $5 \mathrm{ml}$ of the same solution. The supernatants of the lactic acid bacteria cultures were filtered through $0.22 \mu \mathrm{m}$ pore-size filters (Schleicher \& Sehuell, Germany) (Nieto-Lozana et al., 2002; Schillinger et al., 1989).

\section{Determination of Inhibitory Activity}

The inhibitory activities of garlic extract and supernatants were determined by using agar well diffusion analysis. For the agar well diffusion assay $1 \mathrm{ml}$ of the pathogenic microorganisms (with approximately $2.9 \times 10^{8} \mathrm{cfu} / \mathrm{ml}$ ) were inoculated in BHI Broth for $24 \mathrm{~h}$ at $37^{\circ} \mathrm{C}$ and transferred into BHI Agar $(15 \mathrm{ml})$. The resultant mixture was poured into a Petri dish. After the solidification of the agar, $3 \mathrm{~mm}$ diameter wells were cut and $100 \mu \mathrm{l}$ garlic extract, supernatants and their combinations were placed into the wells. The plates were incubated at $37^{\circ} \mathrm{C}$ for $24 \mathrm{~h}$ and checked for inhibition zones (Gonzales et al., 2006). As a control, sterile BHI Broth, which does not contain any microorganism culture, was placed into the one well. All tests were performed in triplicate.

For determination of the inhibitory effect in liquid medium against foodborne pathogenic bacteria, all pathogenic bacteria $\left(10^{7}\right.$ cells $\left./ \mathrm{ml}\right)$ were planted to $10 \mathrm{ml}$ BHI Broth and $1 \mathrm{ml}$ lactic acid bacteria supernatant with garlic extract were added to this culture and were left incubation at $37^{\circ} \mathrm{C}$ for 24 hours. At the end of the incubation, culture was planted to Nutrient Agar by spread method from appropriate dilution and colony counts were performed after incubation at $37^{\circ} \mathrm{C}$ for 24 hours (Nieto-Lozano et al., 2002).

\section{Statistical Analysis}

Variance analysis, ANOVA was performed to evaluate the effect of the inhibitory on the samples and Duncan test was used to compare the means. In all cases the significance level considered was 1\% (Del Castillo et al., 2016).

\section{Results and Discussions}

In our study, inhibitory effects of three different probiotic lactic acid bacterial strains (L. rhamnosus, $L$. acidophilus, L. casei Shirota) and garlic extract were determined by the agar diffusion method and viable cell counts method against food borne pathogen bacteria such as B. cereus, S. Enteritidis, E. coli, Escherichia coli 0157 : $\mathrm{H} 7$, S. aureus. All results are evaluated statistically.

The inhibitory effect of probiotic lactic acid bacteria, garlic extract and their combination determined by agar well diffusion method against all tested food borne pathogen bacteria and the size of inhibition zones measured (Table 1).

As shown in Table 1 all lactic acid bacteria species showed antimicrobial effect against selected pathogenic bacteria. The antimicrobial effect differences of $L$. rhamnosus against all pathogens were significant statistically $(\mathrm{P} \leq 0.01)$. S. aureus was most susceptible strains against $L$. rhamnosus and the most resistant bacteria have been identified as E. coli and E. coli O157: H7. Similarly, L. asidophilus has an antimicrobial effect against all selected pathogens $(\mathrm{P} \leq 0.01)$. S. aureus was most susceptible strains against $L$. acidophilus and the most resistant bacteria have been identified as B. cereus. L. casei Shirota has an antimicrobial effect against all 
pathogens, but it showed the weak inhibitory effect compared to other lactic acid bacteria. S. aureus was most susceptible strains against L. casei Shirota and the most resistant bacteria have been identified as B. cereus. Similar to our study, Sameshi et al., (1998) researched of lactic acid bacteria's effect against $S$. aureus growth and production of enterotoxin at $20^{\circ} \mathrm{C}$ and $30^{\circ} \mathrm{C}$ fermentation temperature. Researchers found that L. rhamnosus FERM P-15120 and L. paracasei subsp. paracasei FERM P15121 inhibits $S$. aureus growth and production of enterotoxin. Chuayana et al. (2003) have investigated the antibacterial activity of isolated from probiotics in dairy products isolated from probiotics in dairy products $S$. aureus, E. coli, $P$. aeruginosa, $S$. Typhi and $S$. marcescens and they reported that $L$. case $i$ have shown a bacteriostatic effect against these pathogens. Similarly, Aslim et al. (2005) reported that L. acidophilus has shown antibacterial activity on $S$. aureus, E. coli and $Y$. enterocolitica in their study.

Garlic extract showed a stronger inhibitory effect against all pathogenic bacteria than the lactic acid bacteria. The most sensitive bacteria have been determined as $S$. aureus of the $26 \mathrm{~mm}$ diameter zone. $S$. aureus followed by $S$. Enteritidis. The results are very close to each other for E. coli O157:H7 and B. cereus when analyzed inhibition effect. The differences between the inhibitory effect of L. rhamnosus and garlic extract combination against pathogenic bacteria was significant by statistically $(\mathrm{P} \leq 0.01)$. The combination of $L$. rhamnosus and garlic extracts $(1: 1 \mathrm{v} / \mathrm{v})$ showed the inhibitory effect against all tested pathogenic bacteria. The most sensitive bacteria were identified as $S$. aureus with $30 \mathrm{~mm}$ zone diameter. Similarly, L. acidophilus and garlic extract combination $(1: 1 \mathrm{v} / \mathrm{v})$ have shown the inhibition effect against all tested pathogenic bacteria and the differences between the inhibitory effect was significant by statistically $(\mathrm{P} \leq 0.01)$. It was determined that $S$. aureus were the most susceptible strains, B. cereus was the most resistant bacteria against L. acidophilus and garlic extracts combination. Also, the differences between the inhibitory effect of $L$. casei Shirota and garlic extract combination against pathogenic bacteria was significant by statistically $(\mathrm{P} \leq 0.01)$. The combination of $L$. casei Shirota and garlic extracts $(1: 1 \mathrm{v} / \mathrm{v})$ showed the inhibitory effect against all tested pathogenic bacteria. And also it has been observed that the most susceptible bacteria was S. aureus.

Table 1 The inhibition zone diameters of probiotic lactic acid bacteria and garlic extract against different foodborne pathogenic bacteria $(\mathrm{mm})$

\begin{tabular}{l|ccccc}
\hline \multicolumn{7}{c|}{ Zone diameter (mm)* } \\
\hline Antimicrobial & B. cereus & S. Enteriditis & E.coli & E.coli O157:H7 & S. aureus \\
L. rhamnosus & $9.6 \pm 0.5774^{\mathrm{Ba}}$ & $10.6 \pm 0.5774^{\mathrm{Cb}}$ & $9 \pm 0.0000^{\mathrm{Aa}}$ & $9 \pm 0.0000^{\mathrm{Aa}}$ & $12 \pm 1.0000^{\mathrm{Dc}}$ \\
L. acidophilus & $9.3 \pm 0.5774^{\mathrm{Aa}}$ & $10 \pm 0.0000^{\mathrm{Bb}}$ & $10.3 \pm 0.5774^{\mathrm{Cb}}$ & $10 \pm 1.0000^{\mathrm{Bb}}$ & $10.6 \pm 1.1547^{\mathrm{Db}}$ \\
L. casei Shirota & $8 \pm 0.0000^{\mathrm{Aa}}$ & $9.3 \pm 0.5774^{\mathrm{Cb}}$ & $8.3 \pm 0.5774^{\mathrm{Ba}}$ & $8.3 \pm 0.5774^{\mathrm{Ba}}$ & $9.6 \pm 0.5774^{\mathrm{Db}}$ \\
Garlic Extract & $15 \pm 1.000^{\mathrm{Aa}}$ & $16 \pm 1.000^{\mathrm{Cb}}$ & $15.3 \pm 0.5776^{\mathrm{Ba}}$ & $15.3 \pm 1.1547^{\mathrm{Ba}}$ & $26 \pm 1.0000^{\mathrm{Dc}}$ \\
L. rhamnosus+G.E. & $15.6 \pm 0.5774^{\mathrm{Aa}}$ & $16.3 \pm 0.5774^{\mathrm{Bb}}$ & $16.3 \pm 1.1547^{\mathrm{Bb}}$ & $15.6 \pm 0.5774^{\mathrm{Aa}}$ & $30 \pm 1.0000^{\mathrm{Cc}}$ \\
L. acidophilus+G.E. & $15.6 \pm 0.5774^{\mathrm{Aa}}$ & $18 \pm 0.0000^{\mathrm{Dd}}$ & $17.3 \pm 0.5774^{\mathrm{Cc}}$ & $16.3 \pm 0.5776^{\mathrm{Bb}}$ & $31.6 \pm 0.5774^{\mathrm{Ee}}$ \\
L. casei Shirota+G.E. & $15.6 \pm 0.5776^{\mathrm{Aa}}$ & $17.3 \pm 1.1547^{\mathrm{Dc}}$ & $16.6 \pm 0.5774^{\mathrm{Cb}}$ & $16 \pm 1.0000^{\mathrm{Bb}}$ & $29.3 \pm 0.5774^{\mathrm{Ed}}$ \\
\hline
\end{tabular}

* The mean values and standard error, ** A-E: The values are sorted from small to large; a-d: The differences between the values shown in different letters are significant statistically $(\mathrm{P} \leq 0.01)$

Table 2 The inhibitory effect of lactic acid bacteria supernatants against pathogenic bacteria in liquid medium (KOB $\log / \mathrm{ml})$

\begin{tabular}{|c|c|c|c|c|}
\hline \multirow{2}{*}{ Pathogenic bacteria } & & \multicolumn{3}{|c|}{ Lactic acid bacteria* } \\
\hline & & L. rhamnosus & L. acidophilus & L. casei Shirota \\
\hline \multirow{3}{*}{ B. cereus } & Control (initial) & 8.17 & 8.17 & 8.07 \\
\hline & Control (24 h) & 8.77 & 8.96 & 8.23 \\
\hline & Counting $(24 \mathrm{~h})$ & 8.57 & 8.43 & 8.11 \\
\hline \multirow{3}{*}{$S$. Enteriditis } & Control (initial) & 8.34 & 8.23 & 8.44 \\
\hline & Control (24 h) & 8.73 & 8.89 & 8.30 \\
\hline & Counting $(24 \mathrm{~h})$ & 8.04 & 8.07 & 8.07 \\
\hline \multirow{3}{*}{ E. coli } & Control (initial) & 8.51 & 8.50 & 8.43 \\
\hline & Control (24 h) & 9.00 & 8.63 & 8.68 \\
\hline & Counting $(24 \mathrm{~h})$ & 8.41 & 8.36 & 8.17 \\
\hline \multirow{3}{*}{ E. coli $\mathrm{O} 157: \mathrm{H} 7$} & Control (initial) & 8.36 & 8.43 & 8.34 \\
\hline & Control (24 h) & 9.00 & 8.77 & 8.65 \\
\hline & Counting $(24 \mathrm{~h})$ & 8.14 & 8.32 & 7.95 \\
\hline \multirow{3}{*}{ S. aureus } & Control (initial) & 8.11 & 8.69 & 8.69 \\
\hline & Control (24 h) & 8.20 & 8.14 & 8.20 \\
\hline & Counting $(24 \mathrm{~h})$ & 6.76 & 8.00 & 8.23 \\
\hline
\end{tabular}

* The mean values (KOB $\log / \mathrm{ml})$ 
Table 3 The inhibitory effect of garlic extract against pathogenic bacteria in liquid medium (KOB log/ml)

\begin{tabular}{|c|c|c|}
\hline Pathogenic bacteria & & orlic extract* \\
\hline \multirow{3}{*}{ B. cereus } & Control (initial) & 8.04 \\
\hline & Control (24. h) & 8.11 \\
\hline & Counting (24. h) & 7.84 \\
\hline \multirow{3}{*}{$S$. Enteriditis } & Control (initial) & 8.83 \\
\hline & Control $(24 . \mathrm{h})$ & $>9.00$ \\
\hline & Counting (24. h) & 8.64 \\
\hline \multirow{3}{*}{ E. coli } & Control (initial) & 8.32 \\
\hline & Control (24. h) & $>9.00$ \\
\hline & Counting (24. h) & 7.00 \\
\hline \multirow{3}{*}{ E. coli $\mathrm{O} 157: \mathrm{H} 7$} & Control (initial) & 8.27 \\
\hline & Control (24. h) & 8.55 \\
\hline & Counting (24. h) & 5.39 \\
\hline \multirow{3}{*}{ S. aureus } & Control (initial) & 8.55 \\
\hline & Control (24. h) & 8.57 \\
\hline & Counting (24. h) & 4.17 \\
\hline
\end{tabular}

*The mean values (KOB $\log / \mathrm{ml})$

Table 4 The inhibitory effect of lactic acid bacteria supernatants and garlic extract combination against pathogenic bacteria in liquid medium (KOB $\log / \mathrm{ml})$

\begin{tabular}{|c|c|c|c|c|}
\hline \multirow{2}{*}{ Pathogenic bacteria } & \multicolumn{4}{|c|}{ Lactic acid bacteria + Garlic Extract* } \\
\hline & & L. rhamnosus+ G.E. & L. acidophilus+ G. E. & L. casei Shirota + G.E. \\
\hline \multirow{3}{*}{ B. cereus } & Control (initial) & 8.53 & 8.53 & 8.53 \\
\hline & Control (24. h) & 9.00 & 9.00 & 9.00 \\
\hline & Counting (24. h) & 8.30 & 8.27 & 8.32 \\
\hline \multirow{3}{*}{ S. Enteriditis } & Control (initial) & 8.46 & 8.46 & 8.46 \\
\hline & Control (24. h) & 8.79 & 8.79 & 8.79 \\
\hline & Counting (24. h) & 4.00 & 4.30 & 4.00 \\
\hline \multirow{3}{*}{ E. coli } & Control (initial) & 8.30 & 8.30 & 8.30 \\
\hline & Control (24. h) & 9.00 & 9.00 & 9.00 \\
\hline & Counting (24. h) & 6.84 & 5.04 & 5.77 \\
\hline \multirow{3}{*}{ E. coli $\mathrm{O} 157: \mathrm{H} 7$} & Control (initial) & 8.17 & 8.17 & 8.17 \\
\hline & Control (24. h) & 8.74 & 8.74 & 8.74 \\
\hline & Counting (24. h) & 5.25 & 5.49 & 6.04 \\
\hline \multirow{3}{*}{ S. aureus } & Control (initial) & 8.89 & 8.89 & 8.89 \\
\hline & Control (24. h) & 8.34 & 8.34 & 8.34 \\
\hline & Counting (24. h) & 4.85 & 5.90 & 5.92 \\
\hline
\end{tabular}

* The mean values (KOB $\log / \mathrm{ml})$

The inhibitory effect of lactic acid bacteria supernatants on pathogenic bacteria in liquid medium has shown in Table 2. As shown in Table 2. when initial alive cell count of $S$. aureus was $8.11 \mathrm{log} \mathrm{cfu} / \mathrm{ml}$ the number of viable cells are fallen to $6.76 \mathrm{log} \mathrm{cfu} / \mathrm{ml}$ after $24 \mathrm{~h}$ of incubation in the sample was added L. rhamnosus supernatant. When considering to the inhibitory effect of L. acidophilus supernatant in a liquid medium on $S$. aureus, initial alive cell count of $S$. aureus was $8.69 \log$ $\mathrm{cfu} / \mathrm{ml}$ the number of viable cells are fallen to $8.00 \mathrm{log}$ $\mathrm{cfu} / \mathrm{ml}$ after $24 \mathrm{~h}$ of incubation. When evaluated on inhibition effect on pathogen bacteria of $L$. acidophilus supernant after 24 hour incubation at broth medium, the most resistant bacteria is $B$. cereus similarly well diffusion method results. In a study investigating the inhibitory effect of lactic acid fermentation on $B$. cereus growth and sporulation, it has been reported $L$. acidophilus has no effect on $B$. cereus sporulation and the sport remains alive (Rossland et al., 2005). When evaluated on inhibition effect on pathogen bacteria of $L$. casei Shirota supernant after 24 hour incubation at broth medium, when the most resistant bacteria is B. cereus similarly, it was shown a similar inhibition effect on well diffusion method results $E$. coli and E. coli O157: H7.

When considering the inhibition effect of garlic extract in the liquid medium, the number of viable cells of S. aureus is $8.55 \log \mathrm{kob} / \mathrm{ml}$ initially, but the number of viable cells of $S$. aureus decreased to $4.17 \mathrm{log} \mathrm{kob} / \mathrm{ml}$ while adding garlic extract substituted after $24 \mathrm{~h}$ incubation (Table 3).

The resistant bacteria have been identified as $B$. cereus like agar well diffusion method when assessing the inhibition effect of garlic extract on pathogenic bacteria after $24 \mathrm{~h}$ incubation. Kumar and Berwal (1998), in a similar study, demonstrated that $5 \%$ ratio of garlic extract using against $S$. aureus has shown an inhibition effect $80 \%$ success. Also, $10 \%$ ratio of garlic extract using for inhibition of $S$. Typhi and $E$. coli has shown a success rate of $90 \%$ success when the ratio of inhibition success against L. monocytogenes has demonstrated $85 \%$. 


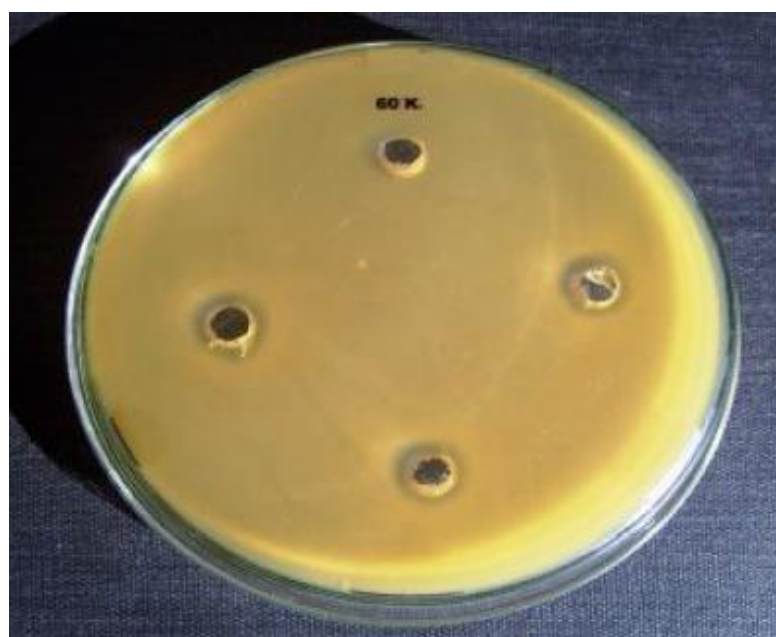

Fig 1 The inhibition effect of Lactobacillus rhamnosus against Staphylococcus aureus by agar well diffusion method (K: Control)

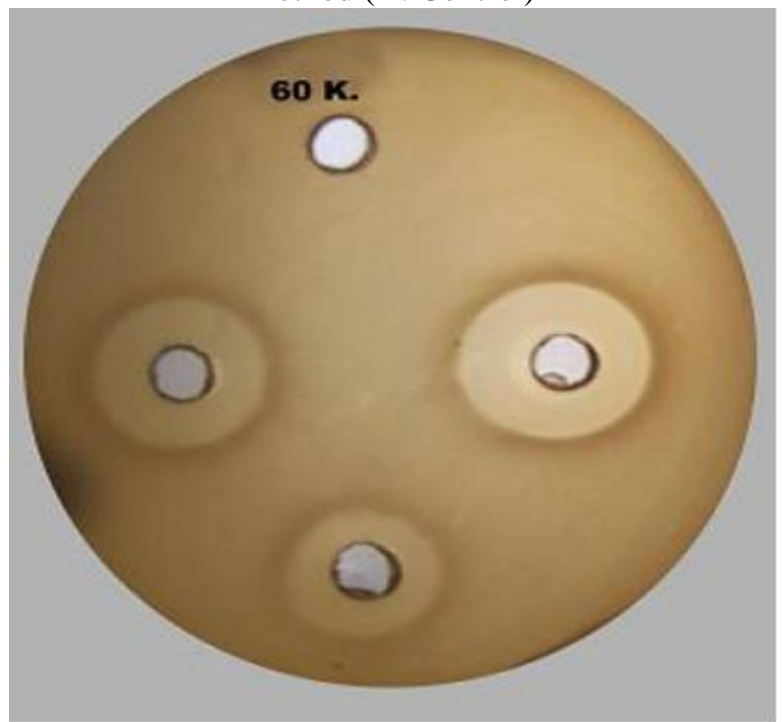

Fig 2 The inhibition effect of garlic extract against Staphylococcus aureus by agar well diffusion method (K: Control)

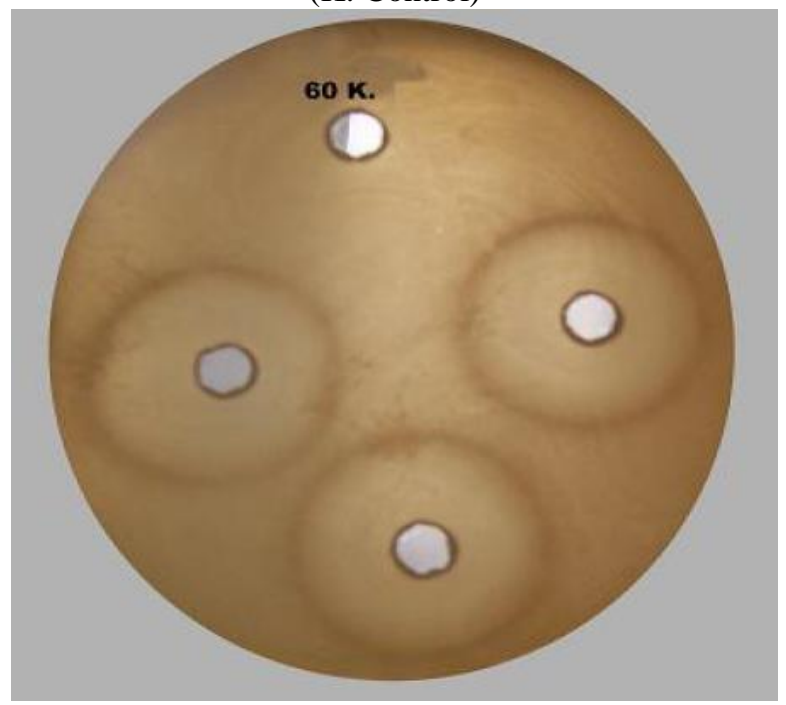

Fig 3 The inhibition effect of Lactobacillus rhamnosus and garlic extract combination against Staphylococcus aureus by agar well difussion method (K: Control)
In another study, researchers have reported that garlic extract have shown an effect against $S$. epidermidis after 1 hour incubation with the rate of 93\%. Similarly, garlic extract has shown a bactericidal effect against $S$. Typhi after 3 hour incubation (Arora and Kaur, 1999). Benkeblia (2004) has researched that the inhibition effect of garlic extract with different ratio against $S$. Enteritidis. The researcher reported that garlic extract has an inhibition effect all tested concentrations and red onion and garlic extracts have shown a very strong inhibitory effect against $S$. Enteritidis.

As shown in Table 4. L. acidophilus and garlic extract showed the maximum inhibition effect against $B$. cereus between other lactic acid bacteria, whereas $L$. casei Shirota showed the weakest inhibition effect. Similarly, $L$. acidophilus and garlic extract showed the maximum inhibition effect against E. coli, whereas L. rhamnosus and garlic extract showed the weakest inhibitory effect. Also L. rhamnosus and garlic extract showed the maximum inhibition effect against E. coli O157:H7, whereas L. casei Shirota and garlic extract showed the weakest inhibitory effect. L. rhamnosus and garlic extract showed the most inhibitory effect against $S$. aureus, whereas L. casei Shirota and garlic extract showed the weakest inhibitory effect. A significant increase is concerned about antimicrobial effect by using garlic extract and lactic acid bacteria as a combination of all strains. S. aureus was determined as the most sensitive bacteria against which using in our study lactic acid bacteria and garlic extract combination (Fig. 1, Fig. 2 and Fig. 3)

Other studies are reported that lactic acid bacteria have more inhibition effect against Gram positive bacteria than Gram negative bacteria (Sobrino the ark., 1991; Makras and De Vuyst; 2006). On the other hand it is stated that Gram negative bacteria came to the vulnerable against bacteriocins when deteriorated of the integrity of the outer membrane of bacteria (Philiphs and Duggan, 2001). Also, it is described that using nisin with combination garlic extract increase to the antimicrobial effect of Nisin (Singh et al., 2001). B. cereus has been identified as resistant bacteria against the combination lactic acid bacteria and garlic extract which using in our research. Rossland et al. (2003; 2005) reported that the inhibitory effect of lactic acid bacteria against $B$. cereus depending on the amount of acid produced is due to the $\mathrm{pH}$ change. And it also described that in same study $B$. cereus retains viability by forming endospores at low rate of $\mathrm{pH}$ change (Rossland et al., 2003; Rossland et al., 2005).

\section{Conclusions}

According to the results of this study, L. rhamnosus showed the maximum inhibition effect against $B$. cereus and $S$. Enteritidis, and also observed that L. casei Shirota showed the weak effect. L. acidophilus showed the maximum inhibition effect against $E$. coli and $E$. coli 0157:H7 whereas L. casei Shirota showed the weak antimicrobial effect. And L. rhamnosus showed the 
maximum inhibition effect against $S$. aureus whereas $L$. casei Shirota showed the weak antimicrobial effect in all tested lactic acid bacteria. According to the obtained results, it was observed that $S$. aureus was the most sensitive bacteria and $B$. cereus was the most resistant bacteria. However, it was determined that L. rhamnosus, the lactic acid bacteria used in this study, have the strong inhibition effect whereas L. casei Shirota have the weakest effect.

Consequently, this study must be expanded and replicated with other pathogenic bacteria as known Gram positive and Gram negative. In addition, it should be investigated whether lactic acid bacteria show the inhibitory effect against yeast and fungi which cause problems in foods. It should be investigated that usage possibilities of probiotic lactic acid bacteria in meat and meat product in future studies.

\section{References}

Andersson A, Rfnner U, Granum PE. 1995. What problems does the food industry have with the spore-forming pathogens Bacillus cereus and Clostridium perfringens?. Int. J. of Food Microbiol. 28: $145-155$.

Arora DS, Kaur J. 1999. Antimicrobial activity of species. Int. J. Antimicrobial Agents. 12: 257-262.

Arqués JL, Rodríguez E, Langa S, Landete JM, Medina M. 2015. Antimicrobial activity of lactic acid bacteria in dairy products and gut: effect on pathogens. BioMed Research Int. Article ID 584183. 9 pages.

Aslım B, Yüksekdăg ZN, Sarıkaya E, Beyatlı, Y, 2005. Determination of the bacteriocin-like substances produced by some lactic acid bacteria isolated from Turkish dairy products. LWT. 38: 691-694.

Benkeblia N. 2004. Antimicrobial activity of essential oil extracts of various onions (Allium cepa) and garlic (Allium sativum). LWT. 37: 263-268.

Boyce TG, Pemberton AG, Wells JG, Griffin PM. 1995. Screening for Escherichia coli O157: H7-a nationwide survey of clinical laboratories. J. Clin. Microbiol. 33(12): 3275-3277.

Casella S, Leonardi M, Melai B, Fratini F, Pistelli L. 2013. The role of diallyl sulfides and dipropyl sulfides in the in vitro antimicrobial activity of the essential oil of garlic, Allium sativum L. and leek Alliumporrum L. Phytother. Res. 27: 380-383.

Chuayana Jr EL, Ponce CV, Rivera MRB, Cabrera EC. 2003. Antimicrobial activity of probiotics from milk products. Phil. J. Microbiol. Dis. 32 (2): 71-74.

Cizeikiene D, Juodeikiene G, Paskevicius A, Bartkiene E. 2013. Antimicrobial activity of lactic acid bacteria against pathogenic and spoilage microorganism isolated from food and their control in wheat bread. Food Cont. 31: 539-545.

Daka D. 2011. Antibacterial effect of garlic (Allium sativum) on Staphylococcus aureus: An in vitro study. Afr. J. of Biotechnol. 10 (4): 666-669.

Del Castillo V, Goldner MC, Armada M. 2016. Evaluation of texture profile, color and determination of FOS in yacón products (Smallanthus sonchifolius). Turk. J. of Agriculture Food Sci. and Technol.4(7): 540-544.

Ghanbari M, Jami M, Domig KJ, Kneifel W. 2013. Seafood biopreservation by lactic acid bacteria-A review. LWT-Food Sci. and Technol. 54: 315-324.

Gonzalez L, Sandovel H, Sacristan N, Castro JM, Fresno JM, Tornadijo ME. 2006. Identification of lactic acid bacteria isolated from genestoso cheese throughout ripening and study of their antimicrobial activity. Food Control. 18: 716-722.

Granum PE, 2001. Bacillus cereus. In: Doyle, M.P., Beuchat, L.R., Montville, T.J. (Eds.), Food Microbiology. Fundamentals and frontiers, second edition. ASM Press, Washington, DC. 373 $381 \mathrm{pp}$.
Gulfraz M, Imran M, Khadam S, Ahmed D, Asad MJ, Abassi KS, Irfan M, Mehmood S. 2014. A comparative study of antimicrobial and antioxidant activities of garlic extract in various localities of Pakistan. Afr. J. of Plant Sci. 8(6): 298-306.

Hayaloğlu AA, Erginkaya Z. 2001. Gıda endüstrisinde kullanılan laktik asit bakterileri. Gıda Teknolojileri Derneği Yayın No:23. Ankara.

Indu MN, Hatha AMM, Abirosh C, Harsha U, Vivekanandan G. 2006. Antimicrobial activity of some of the South-Indian spices against serotypes of Escherichia coli, Salmonella, Listeria monocytogenes and Aeromonas hydrophila. Brezillian $\mathrm{J}$. Microbiol. 37:153-158.

Kumar M, Berwal JS. 1998. Sensitivity of food pathogens to garlic (Allium sativum). J. App. Microbiol. 84: 213-215.

Kumar Y, Agarwal S, Srivastava A, Kumar S, Agarwal G, Khan MZA. 2014. Antibacterial activity of clove (Syzygium aromaticum) and garlic (Allium sativum) on different pathogenic bacteria. Int. J. Pure App. Biosci. 2 (3): 305-311.

Kyung KH. 2012. Antimicrobial properties of allium species. Current Op. in Biotechnol. 23:142-147.

Larsen HD, Jørgensen K. 1997. The occurrence of Bacillus cereus in Danish pasteurized milk. Int. J. of Food Microbiol. 34: 179186.

Li G, Ma X, Deng L, Zhao X, Wei Y, Gao Z, Jia J, Xu J, Sun C. 2015. Fresh garlic extract enhances the antimicrobial activities of antibiotics on resistant strains in vitro. Jundishapur Microbiol. 8(5): 14-18.

Makras L, De Vuyst L. 2006. The in vitro inhibition of Gramnegative pathogenic bacteria by Bifidobacteria is caused by the production of organic acids. Int. Dairy J. 16: 1049-1057.

Mayr R, Eppert I, Scherer S. 1999. Incidence and identification of psychrotrophic (7 degrees C-tolerant) Bacillus spp. in German HTST pasteurized milk. Milchwissenschaft. 54: 26-30.

Meer RR, Baker J, Bodyfelt FW, Griffiths MW. 1991. Psychotropic Bacillus spp. in fluid milk-products-a review. J. of Food Pro. 54: 969-979.

Mukhtar S, Ghori I. 2012. Antibacterial activity of aqueous and ethanolic extracts of garlic, cinnamon and turmeric against Escherichia coli ATCC 25922 and Bacillus subtilis. 3(2): ISSN:0976-4550.

Nieto-Lozano JC, Raguera-Useros JI, Pelaez-Martinez MC, De La Torre AH. 2002. Bacteriocinogenic activity from starter cultures used in Spanish meat industry. Meat Sci. 62: 237-243.

Öz F, Kaya M, Aksu Mİ. 2002. Sucuk üretiminde farklı nitrit dozlarının ve starter kültür kullanımının Escherichia coli O157:H7'nin gelişimi üzerine etkisi. Türk J Vet. Anim. Sci. 26: 651-657.

Pascual MO, Hugas M, Badiola JI, Monfort JM, Garriga M. 1999. Lactobacillus salivarius CTC2197 prevents Salmonella Enteritidis colonization in chickens. App. and Env. Microbiol. 65 (11): 4981-4986.

Philips CA, Duggan J. 2001. The effect of EDTA and trisodium phosphate, alone and in combination with nisin, on the growth of Arcobacter butzleri in culture. Food Microbiol. 18: 5547-554.

Ranjan S, Dasgupta N, Saha P, Madhumita Rakshit M, Cizeikiene R. 2012. Comparative study of antibacterial activity of garlic and cinnamon at different temperature and its application on preservation of fish. Adv. in App. Sci. Research. 3(1): 495-501.

Reis JA, Paula AT, Casarotti SN, Penna ALB. 2012. Lactic acid bacteria antimicrobial compounds: characteristics and applications. Food Eng Rev. 4:124-140.

Rossland E, Langsrud T, Sorhaug T. 2005. Influence of controlled lactic fermentation on growth and sporulation of Bacillus cereus in milk. Int. J. Food Microbiol. 103: 69-77.

Rossland E, Morge GIA, Langsrud T, Sorhaug T. 2003. Inhibition of Bacillus cereus by strains of Lactobacillus and Lactococcus in milk. Int. J. Food Microbiol. 89: 205-212.

Sameshima T, Magome C, Takeshita K, Arihara K, Itoh M, Kondo Y. 1998. Effect of intestinal Lactobacillus starter cultures on the behavior of Staphylococcus aureus in fermented sausages. Int. Journal of Food Microbiol. 41: 1-7. 
Schillinger U, Lucke FK. 1989. Antimicrobial activity of Lactobacillus sake isolated from meat. App. and Env. Microbiol. 55(8): 1901-1906.

Singh B, Falahee MB, Adams MR. 2001. Synergistic inhibition of Listeria monocyttgenes by nisin and garlic extract. Food Microbiol. 18: 133-139.

Siroli L, Patrignani F, Serrazanetti D, Tabanelli G, Montanari C, Gardini F, Lanciotti R. 2015. Lactic acid bacteria and natural antimicrobials to improve the safety and shelf-life of minimally processed sliced apples and lamb's lettuce. Food Microbiol. 47: $74-84$
Sobrino O, Rodriguez JM, Moreira WL, Fernandez MF, Sanz B, Hernandez PE. 1991. Antibacterial activity of Lactobacillus sake isolated from dry fermented sausages. Int. J. Food Microbiol. 13: 1-10. 